\title{
TSITAATSÕNA HÄÄLDUSEST EESTI KEELES JA SELLE ESITUSEST SÕNASTIKES
}

\author{
TIINA PAET
}

\begin{abstract}
Annotatsioon. Artikkel annab lühiülevaate tendentsidest tsitaatsõna häälduses eesti keeles ja keskendub probleemile, kas tsitaatsõnade häälduseks märgitud häälduskuju ja tegelik kasutus langevad kokku ehk kas keelekasutajad järgivad sõnastikesse märgitud häl̈lduskuju. „Võõrsõnade leksikoni” 7. trükist (VL 2006), „Eesti keele seletavast sõnaraamatust” (EKSS), „Eesti õigekeelsussõnaraamat ÕS 2006-st” (ÕS 2006) ja „Võõrsõnade leksikoni” (VL) 8. trüki käsikirjast valiti välja 63 märksõna (neist 52 on tsitaatsõnad ja -väljendid), mille põhjal korraldati häälduskatsed. Küsitleti kahte rühma eesti emakeelega katseisikuid: 15 kõrgharidusega (v.a filoloogiharidusega) inimest ja 15 eesti filoloogi haridusega inimest. Katsete eesmärk oli selgitada, kuidas katsealused tsitaatsõnu hääldavad. Tulemused näitavad, et üsna palju esineb mugandatud hääldamist, inglispäraselt hääldatakse ka teistest keeltest pärit sõnu. Katsed aitavad selgitada tendentse tsitaatsõna häälduses ja seda, kas erandjuhtudel võiks sõnaraamatus esitada peale originaalhäälduse ka eesti mugandhäälduse. Saadud tulemused aitavad otsustada, mis kujul on kõige otstarbekam esitada tsitaatsõnade hääldust eesti ükskeelseis üldkeele sõnaraamatuis (eelkõige võõrsõnade leksikonis, aga ka eesti keele seletavas sõnaraamatus ja õigekeelsussõnaraamatus).
\end{abstract}

Võtmesõnad: leksikograafia, leksikoloogia, mugandhääldus, võõrsõna, võõrsõnade leksikon

\section{Sissejuhatuseks}

Eesti keeles on tsitaatsõnad ja -väljendid struktuurivõõruse skaalal kõige võõramad keelendid. „Eesti keele käsiraamatu” järgi kirjutatakse neid „,nagu võõrkeeles, kust nad on võetud. Hääldus on võõrkeelelähedane” (EKK: 76). Tuleb möönda, et öeldu kehtib küll üksnes nende keelendite kohta, mis tulevad ladina tähestikku tarvitavatest keeltest. Tsitaatkeelendid eristatakse muust tekstist teise, nt kursiivkirjaga.

Viimastel aastatel on eestikeelsetes tekstides tsitaatsõnade osatähtsus tunduvalt kasvanud, seetõttu on päevakorda tõusnud küsimus, kuidas neid 
ohtralt tarvitatavaid keelendeid hääldatakse. Tiina Leemets (2003: 573) on täheldanud tsitaatsõnade osakaalu suurenemist ka sõnaraamatutes.

Eesti keeles käsitlevad tsitaatsõna mõistet ja hääldusreeglit vaid üksikud grammatikad, samuti ei leia enamiku eesti ükskeelsete sõnaraamatute eessõnadest ega kasutusjuhistest kuigivõrd infot tsitaatsõna ega selle häälduse esituse kohta vastavas teoses. Uurimuse teoreetiline osa keskendubki tsitaatsõna mõiste käsitlusele eesti keeleteaduses ja sõnaraamatutes.

Otsene vajadus ja huvi uurida tsitaatsõnu ja -väljendeid ning korrastada nende häälduse esitust tekkis võõrsõnade andmebaasi ajakohastamise ${ }^{1}$ ja „Võõrsõnade leksikoni” toimetamise käigus 8. trüki tarvis. Samuti tekitas küsimusi asjaolu, et tsitaatsõnade häälduse esitusel eesti ükskeelseis sõnastikes ilmneb mõningaid erinevusi.

\section{Tsitaatsõna käsitlusest eesti keeleteaduses}

Johannes Aaviku 1933. aastal ilmunud raamat ,20 Euroopa keelt” kujutab endast 20 Euroopa keele võõrpärisnimede ning tsitaatsõnade ja -lausete hääldamise õpetust. Pearõhk on eeskätt võõrnimede häälduse käsitlusel, kuid näidete hulgas esineb rohkelt ka tsitaatsõnu ja -lauseid. Raamatu lõpus on ladina tsitaatlausete kogu.

Aavik märgib ladinakeelsetel tsitaatsõnadel nii pikka vokaali kui ka rõhku. Ladina tsitaatlausetes Aavik hääldust eraldi ei märgi, vaid paneb pika vokaali tähistamiseks vastava vokaali kohale pikenduskriipsu, rõhku märgib ta akuudiga (') rõhulise silbi vokaali kohal, nt currículum vìtae, quō vadis?, sīc. (Aavik 1933).

Aavik leiab, et on põhimõtteline küsimus, millise piirini tuleb eesti keeles järgida võõrnimede originaalhääldust, ja nendib, et võõrnimede hääldamine võib olla teataval määral lihtsustatud - ,,eestipärastet kompromisshääldamine". Ta toonitab, et eesti keeles on traditsioon järgida ladina keele hääldusel samu reegleid nagu saksa keeles.

Käesoleva uurimuse seisukohast on olulisemad punktid Aaviku antud hääldusjuhistes järgmised (Aavik 1933).

1. Ladina keele ae häälduseks märgib Aavik $\ddot{a}(\ddot{a})$, seda järgib ka ÕS 2006. (Seevastu LES annab ae häälduseks ee.)

Võõrsõnade andmebaasi ajakohastamist on toetanud riiklik programm „Eesti keel ja kultuurimälu”. 
2. Prantsuse nimede lõppsilbi häälduseks on Aavik paljudel juhtudel andnud $\ddot{a} \ddot{a}$, nt Baudelaire [bodläär], tänapäeval tavatsetakse seda pigem $e e$-na hääldada. Prantsuse $a i$, ei häälduseks märgib Aavik juhistes: „,̈ poole kalduv $e$ ", ent hääldustes on sageli ka $\ddot{a}$, mõnikord $e$ või mõlemad variandid, nt Saint Hilaire [säntileer, -läär].

3. Inglise nimedes eelistab Aavik diftongidele pikki vokaale, osa nimesid on saanud ka kaks hääldust, nt Taylor [teilor, teelor].

Ernst Nurm vaeb eesti keele hääldusküsimusi 1935. aastal, olles seisukohal, et õigele hääldusele pööratakse kooliõpetuses liiga vähe tähelepanu. Käesoleva artikli mõistes tsitaatsõnu Nurm ei käsitle, puudutab aga võõrsõnade hääldust. (Nurm 1935: 185-186)

1936. aastal kordab Johannes Aavik taas, et võõrsõnu, mida tarvitatakse eesti keeles juhuslikult ja mida kasutatakse võõrkeelses kirjaviisis, võiks nimetada tsitaatsõnadeks (Aavik 1936).

Erich Raiet kasutab oma 1966. aastal valminud väitekirjas terminit tsitaatsõna, viidates Johannes Aavikule (Raiet 1966: 18).

1968. aastal ilmunud Johannes Valgma ja Nikolai Remmeli „Eesti keele grammatikast” tsitaatsõnade ortograafia, morfoloogia ega häälduse kohta materjali ei leia (Valgma, Remmel 1968).

Küll aga tarvitab terminit tsitaatsõna Valter Tauli 1968. aastal, öeldes: „Kui võõrkeelest pärit sõna tarvitatakse kui sõnavara täieõiguslikku liiget, mitte tsitaatsõnana, siis peaks teda kirjutama sama reegli järgi kui omasõnu" (Tauli 1968: 166). 1972. aastal nimetab Tauli tsitaatväljendeid võorkeelseteks väljenditeks, ent nende hääldusküsimust ta ei puuduta (Tauli 1972: 27).

1993-1995 ilmunud „Eesti keele grammatikast” (EKG I-II) ei leia tsitaatsõnade kohta informatsiooni.

Tsitaatsõna käsitleb Tiiu Erelt oma „Eesti ortograafias”, kus ütleb järgmist: „Tsitaatsõnad ja -väljendid on puhtvõõrkeelsed ning neid kirjutatakse ja hääldatakse nagu võõrkeeles, kust nad on võetud" (Erelt 1995: 15). ,Eesti keele käsiraamatu” järgi hääldatakse tsitaatsõnu ,,vastava keele kombe kohaselt, mis erineb eesti omast” (EKK: 611) ning „Eesti ortograafiast” pärit sõnastuses: „Tsitaatsõnad ja -väljendid on puhtvõõrkeelsed ning neid kirjutatakse nagu võõrkeeles, kust nad on võetud. Hääldus on võõrkeelelähedane” (EKK: 76-77).

1999. aastal ilmunud „Maailma kohanimedes” kasutab Peeter Päll terminit tsitaatsõna võõrnimede ja tsitaatsõnade võrdlemisel (MKN 1999: 9). 
Võõrnimesid hääldatakse üldjuhul samuti kui tsitaatsõnugi originaalkeelelähedaselt, seetõttu on tsitaatsõna ja võõrnime häälduse kõrvutus täiesti asjakohane. Samuti kehtivad õigekeelsussõnaraamatute lõpus olevad võõrnimede hääldusjuhised põhimõtteliselt ka tsitaatsõnade kohta, ent seda ei mainita üheski sõnaraamatus.

\section{Tsitaatsõnad eesti sõnaraamatutes}

Et eesti keele grammatikates pööratakse tsitaatsõnadele suhteliselt vähe tähelepanu, siis on asjakohane vaadelda tsitaatsõnade ja nende häälduse esitust olulisemates eesti ükskeelsetes sõnaraamatutes läbi aegade. Esmalt on vaatluse all võõrsõnastikud, seejärel õigekeelsus- ja seletussõnaraamatud.

\subsection{Tsitaatsõnad võ̃̃rsõnastikes}

Esimesed päris võõrsõnastikud koostasid ja avaldasid Herbert Haljaspõld ja August Voldemar Kõrv.

1930.-1931. a ilmus Herbert Haljaspõllult kõvakaaneliste vihikutena „Võõrsõnade leksikon”. Teos sisaldab hulganisti käesoleva uurimuse mõistes tsitaatsõnu, muust tekstist neid kirjaga ei eristata. Hääldus on seesugustel sõnadel märgitud ümarsulgudesse märksõna järele, selle ette on märgitud lühend $l$. (loe), nt agrément (l. agremaan) (VL 19301931: 21).

Häälduse märkimine on üsna ebajärjekindel. Kohati on märgitud vaid kirjapildist erinev häälduse osa, kohati terve hääldus. Üldjuhul on märkimata jäetud saksa ja ladina tsitaatsõnade ning -väljendite hääldus, märgitud on prantsuse ja inglise tsitaatsõnade hääldus. Mõnikord hääldus puudub, ehkki ei lange kirjapildiga kokku, nt pole hääldust märgitud märksõnal last but not least, teinekord on märgitud üksnes osa hääldusest, ehkki ka muus osas ei lange kirjapilt hääldusega kokku, nt le roi est mort, vive le roi (l. löroa). Häälduse märkimisel on kasutatud harilikke eesti kirjatähti. Üldjoontes võib arvata, et on püütud märkida seda osa hääldusest, mis võiks leksikoni kasutajale raskusi valmistada.

1933. aastal ilmunud Haljaspõllu „Väike võõrsõnastik” (VVS) on koostatud samade põhimõtete järgi nagu VL 1930-1931, ent ei sisalda lisana käesoleva uurimuse mõistes tsitaatsõnu. Nendel puhtvõõrkeelsetel 
sõnadel, mis teoses sisalduvad, on hääldus märgitud samade põhimõtete järgi kui VLis 1930-1931.

1937. aastal ilmus Haljaspõllult „Suur võõrsõnade leksikon”, mis on 1930-1931. a „Võõrsõnade leksikoni” 2., täiendatud trükk². Märksõnastik on suurenenud peamiselt terminite poolest. Tiitellehel on kirjas, et teos sisaldab ligi 35000 võõrsõna ja ,,võõrkeelset ütelust ja tarksõna seletuste, päritolumärkmete ja hääldamisreeglitega" (SVL). Tõsiasi, et häälduse kui olulise struktuurielemendi olemasolust antakse teada juba tiitellehel, äratab tähelepanu. Tegu on siiski üksnes häälduse märkimisega märksõna järel ja mitte reeglistikuga. Võrreldes eelmise trükiga on 1937. aasta leksikonis näha trükitehniliste olude paranemist. Häälduse märkimises tähendab see muu hulgas, et on võimalik kirjutada $s h$ asemel $\check{s}$. Muus on häälduse märkimise põhimõtted samad kui VLis 1930-1931. Üldjuhul antakse hääldus prantsuse, itaalia ja inglise päritolu sõnadel. Puhtvõõrkeelseid märksõnu kursiiviga ei eristata.

1935. aastal ilmus Kõrvi „Õpilase võõrsõnastik”, mis on koostatud „Eesti õigekeelsus-sõnaraamatu”, Haljaspõllu 1930.-1931. a „Võõrsõnade leksikoni” ja 1933. a „Väikese võõrsõnastiku” põhjal. Sõnavalikust on välja jäetud spetsiifilisemad sõnad, sest sõnastik on mõeldud õpilastele. Üldjoontes sisaldab Kõrvi „Õpilase võõrsõnastik” üksikuid käesoleva uurimuse mõistes tsitaatsõnu, nt ex officio, lühendeid ibid. ja id. Hääldust ei märgita ning tsitaatmärksõnu muudest märksõnadest ei eristata.

Sõjajärgsetel aastatel olid Eesti-aegsed teatmeteosed keelatud, seetõttu tekkis suur vajadus võõrsõnade kogu järele.

1961. aastal ilmunud Richard Kleisi, Johannes Silveti ja Eduard Vääri „Võõrsõnade leksikoni” eessõnas ega kasutusjuhistes terminit tsitaatsõna ei tarvitata, asjakohaseid keelendeid nimetatakse võõrkeelseteks sõnadeks ja väljenditeks (VL 1961). Seesugused märksõnad esitatakse kursiivis ja nende hääldus märgitakse juhul, kui see erineb eesti reeglipärasest hääldusest, hääldus antakse kas tervele sõnale või üksnes sõnaosale, mille hääldus erineb kirjapildist.

1983. a ilmunud „Võõrsõnade leksikoni” 5. trüki eessõnas nimetatakse käesoleva töö mõistes tsitaatsõnu ja -väljendeid võõrkeelseiks märksõnadeks ja piirdutakse juhisega: ,nende hääldamine, niivõrd, kuivõrd see erineb nende kirjakujule vastavast eesti hääldamisest, näidatakse nurksulgudes ja kursiivis" (VL 1983: 7).

2 Samal aastal ilmus ka 3. trükk nimetuse all „Entsüklopeediline võõrsõnastik”. 
2000. a ilmunud 6., uuendatud trüki peatükis „Teadmiseks „Võõrsõnade leksikoni" kasutajale" antakse kasutussoovitusi, käesoleva töö mõistes tsitaatsõnu ja -väljendeid nimetatakse võorkeelseteks sõnadeks ja väljenditeks. Viimaste hääldusjuhistes öeldakse järgmist: „Hääldusmärkidena kasutatakse harilikke kirjatähti. Pikki täishäälikuid märgitakse rõhtkriipsuga tähe peal (nt credo [kre--]); ninahäälikuid [nasaale - T. P.] märgitakse tähega $n$ hääliku järel sulgudes (nt façon [-só(n)])" (VL 2000: 7-8). Huvitav on see, et alates sellest trükist leiab „Võõrsõnade leksikonist" lingvistikaterminiks märgitud tsitaatsõna 'võõrkeelne sõna tekstis, mis hrl tõstetakse esile teise kirjaga' (artiklis „tsitaat”).

Järgmise, 2006. a ilmunud 7., parandatud ja täiendatud trüki hääldusjuhistes ei ole tsitaatsõnade ega nende häälduse kohta midagi lisatud. Miskipärast on välja jäetud seletus nasaalide märkimise kohta. Juhis rõhu tähistamise kohta käib nagu eelmisegi trüki sissejuhatavas peatükis „harilike, eesti õigekirjutuse reeglite kohaselt kirjutatavate” märksõnade kohta, ehkki kehtib ka tsitaatsõnade ja -väljendite kohta: rõhku tähistatakse rõhulise silbi täishääliku järel sirge apostroofiga (VL 2006: 7).

VL 2006 peatükis „Leksikoni kasutajale” on lõik rõhu märkimise kohta ja lause „Võõrkeelsete märksõnade järel on näidatud nurksulgudes ja kursiivkirjas hääldus, niivõrd kui see erineb nende sõnade kirjakujule vastavast hääldusest."

1999. a ilmunud Tea kirjastuse „Võõrsõnastikus” (VS 1999) kasutusjuhised puuduvad. Sõnastiku lõpus on lisana esitatud ladina tsitaatväljendid, mida nimetatakse ladina kõnekäändudeks. Viimastel esitatakse hääldus kaldkriipsude vahel. Häälduses on märgitud rõhk, pikad vokaalid on märgitud kahekordse tähega. Ka sõnastikuosas leidub tsitaatsõnu ja -väljendeid, ent neile ei ole antud hääldust.

\subsubsection{Tsitaatsõnad 2006. ja 2012. aasta „Võõrsõnade leksikonis”}

2006. aastal ilmunud „Võõrsõnade leksikoni” 7. trükk sisaldab ligi 35000 märksõna. Tsitaatsõnaartikleid on VL 2006-s kokku 3824, seega üle 10\% märksõnade koguarvust, ligi 3000-le neist on märgitud hääldus. Peale tsitaatsõnade on hääldus märgitud ka 3964 märksõnal, mis ei ole tsitaatsõnad, peamiselt on märgitud rõhk.

„Võõrsõnade leksikoni” 8. trüki (ilmub tõenäoliselt 2012) ettevalmistamisel kasutatakse tsitaatkeelendite häälduse toimetamisel vastavate keelte tundjate abi. 
VLi 8. trükis väheneb tsitaatmärksõnade hulk selliste keelendite arvelt, millel pole väljendi väärtust ja mis kuuluvad pigem kakskeelsesse sõnastikku, nt robe de chambre, car, exhibition.

Lisatakse tsitaatmärksõnu, mis on eestikeelsetes tekstides kasutust leidnud viimasel ajal, nt acquis, caffè latte, outlet.

\subsection{Tsitaatsõnad õigekeelsus- ja seletussõnaraamatutes}

Õigekeelsussõnaraamatute traditsiooni alustasid ,Eesti keele õigekirjutuse-sõnaraamat” (EKÕS, 1918) ja „Eesti õigekeelsuse-sõnaraamat” (I-III, 1925-1937), milles leidub ka võõrsõnu.

„Eesti õigekeelsuse-sõnaraamatus” (EÕS) antakse käesoleva artikli mõistes tsitaatsõnad (nt crescendo) harilikus kirjas ja ilma häälduseta. Mitmed tsitaatsõnad esitatakse nurksulgudes ja nende juurest juhatatakse vaatama mugandit, nt [café] vt. kafee, kohvik. Elmar Muugi 1946. a ${ }^{3}$ ilmunud „Väikese õigekeelsussõnaraamatu” tähtsamates õigekirjutusjuhistes on kirjas: „Eesti kirjaviisi jäetakse üle kandmata ka võõrkeelsed kõnekäänud, näit.: de facto, ex officio, à la fourchette, all right, trade mark jne., samuti rahvusvahelised muusikalised noodinimetused ning ettekandeviisijuhted: do, re, mi, .. allegro .. " (VÕS 1946: 17). Nimetatud sõnadest on märksõnadena sõnaraamatus sees $d o, r e, m i$, mis on sõnastikuosas esitatud püstkirjas. Hääldusest kasutusjuhistes ei räägita. Kohanimede hääldus antakse nurksulgudes.

1948. aastal ilmunud „Suure õigekeelsus-sõnaraamatu” 1. vihiku kasutusjuhistes öeldakse võõrnimede häälduse kohta, et see antakse kursiivkirjas ja sulgudes. Tsitaatsõnu nimetatakse ,sõnadeks, mis ei kuulu otseselt eesti sõnavarasse, kuid on siiski erialaste terminitena või rahvusvaheliste väljenditena meil tuntud" (SÕS 1948: 11). Sealsamas räägitakse ka ,võõrkeelsetest kursiiviga märgitud sõnadest”, mille puhul tuleb tarvitada lisamärke vastava keele ortograafia kohaselt. Seesugused märksõnad antakse SÕSis kursiivkirjas, nt andante. Nendel sõnadel esitatakse hääldus juhul, kui see erineb kirjapildist, nt accelerando [atšelera'ndo].

1976. a ÕSi aluseks on täiendatud ja ümbertöötatud 1960. a ÕS. Pidades silmas mahtu, jäeti muu hulgas välja ka haruldasemaid võõrsõnu. Käesoleva uurimuse mõistes tsitaatsõnu nimetatakse võõrkeelseteks kursiiviga märgitud sõnadeks (ÕS 1976: 9) ja puhtvõõrkeelseteks väljenditeks

${ }^{3}$ VÕSi 1. trükk ilmus 1933. aastal. 
(ÕS 1976: 875). 1976. a ÕSi sõnastikuossa on lisatud märksõna tsitaatsõna koos valdkonnamärgendiga.

ÕS 1976 annab raamatu lõpus asuvas lisas põhjalikud teiskeelsete nimede hääldusjuhised (ÕS 1976: 903), ent tsitaatsõnade hääldust ei puudutata. Sõnaraamatu sõnastikuosas märgitakse tsitaatsõnade hääldus märksõna järel nurksulgudes.

1999. a ilmunud õigekeelsussõnaraamat (ÕS 1999) annab teiskeelsete nimede hääldamise juhised raamatu lõpus (samuti kui eelnevad ÕS 1960 ja ÕS 1976 ning järgnev ÕS 2006). Ka teksti sisu on peamiselt sama, kadunud on vaid lõik tendentsi kohta hääldada võõrnimesid osaliselt või täiesti kirjapildi järgi. Tsitaatsõnu ega nende hääldust ÕS 1999 (ega ka ÕS 2006) kasutusjuhistes eraldi ei käsitle. Küll on mõlema sõnaraamatu sõnastikuosas antud märksõna tsitaatsõna koos seletusega 'keeleteaduses: võõrkeelne sõna eestikeelses tekstis, nt show, de facto'. Võrreldes ÕS 1999-ga sisaldab 2006. a ÕS 23 uut tsitaatsõna, nt baguette, caffè latte, croissant, hot dog, management, slogan. Hääldus esitatakse ÕS 1999-s ja ÕS 2006-s noolsulgudes. Häälduse esitus on mõnevõrra ebaühtlane: kord antakse üksnes kirjapildist erinev hääldusosa (nt pardon $<-$ doon $>$ ), kord kogu märksõna hääldus (nt opus citatum <opus tsitaatum>) .

1988. aastal ilmunud „Eesti kirjakeele seletussõnaraamatu” I köite 1. vihikus on sõnaraamatu ülesehituse peatükis kasutatud terminit tsitaatsõna ja öeldud järgmist: „Märksõna juurde kuuluv ainestik on eri laadi märksõnade puhul erinev; üldiselt on see esitatud järgmiselt: 1) tarbe korral (näit. tsitaatsõnade puhul) hääldus (püstkirjas, nurksulgudes) .." (EKKSS I,1: 23), „nurksulgudes on .. vajaduse korral lisatud hääldus (eriti tsitaatsõnade puhul)" (ibid.: 13). Sõnaraamat esitab märksõnadena lingvistikaterminid tsitaatlaen 'võõrkeelne sõna v. väljend tekstis' ja tsitaatsõna 'võõrkeelne sõna tekstis' (EKKSS VI,2).

Ka „Eesti keele seletava sõnaraamatu” (2009) eessõnas kasutatakse terminit tsitaatsõna ja märgitakse seoses sellega järgmist: „Valikuliselt on sõnaraamatus esitatud .. tsitaatsõnu (anno, talk show).” Tsitaatsõnade hääldusest räägitakse seoses häälduse esitusega üldiselt EKSSis: „Hääldus on esitatud tarbe korral, enamasti tsitaatsõnade puhul, aga ka mõnede lühendite puhul. Hääldus on antud püstkirjas ja nurksulgudes, näiteks yuppie [japi], CV [tsee-vee]" (EKSS: 9).

Kokkuvõtteks võib öelda, et tsitaatsõnade vormistamine sõnaraamatus kursiivkirjas sai alguse hiljemalt 1948. aasta SÕSis. Tsitaatsõnadeks 
nimetas võõrkeelseid sõnu ja väljendeid Johannes Aavik juba 1936. aastal, Erich Raiet toetas selle termini kasutamist (1966). Edasi leiab nimetatud termin käsitlemist Tiiu Erelti „Eesti ortograafias” (1995 ja järgmised trükid, peale tsitaatsõna ka tsitaatväljend), Mati Erelti, Tiiu Erelti ja Kristiina Rossi „Eesti keele käsiraamatus” (1997 ja järgmised trükid) ning Peeter Pälli „Maailma kohanimedes” (1999). Sõnaraamatu kasutusjuhistesse jõudis tsitaatsõna esimest korda 1988. aastal (EKKSS I,1) ning sõnaraamatu sõnastikuossa 1976. aastal (ÕS 1976).

\section{Häälduskatsed}

Tsitaatsõnade häälduse uurimiseks on üks võimalus teha katseid. Käesolevate katsete eesmärk oli selgitada, kas keelekasutajad järgivad oma häälduses sõnastikesse märgitud häälduskuju, ja selle põhjal otsustada, milline on kõige otstarbekam ja kasutajasõbralikum häälduse esituse viis eesti ükskeelses sõnaraamatus.

Katsete jaoks valisin välja 63 märksõna, mida palusin katsealustel hääldada. Põhiosa neist (52 märksõna) olid tsitaatsõnad ja -väljendid, 2 suurtähtlühendid, mida kirjutatakse nii kursiivis kui ka püstkirjas (loendis püstkirjas). Lisaks olid loendis lihtsama hääldusega võõrsõnad ja võõrsõnaühendid (esitatud püstkirjas), mille puhul võis eeldada, et katseisik tuleb nende hääldusega toime, ja mis seetõttu olid mõeldud katsealusele keerukamate häälduste vahel puhkuseks ja tähelepanu taaskoondamiseks. Osa seesuguste sõnade ja sõnaühendite (aadress, Newfoundlandi koer, šokolaad, zooloogia) hääldust oli võimalik ka uurida.

Põhiosa, 52 märksõna olid eestikeelsetes tekstides kasutatavad muganemata võõrsõnad, mida kirjutatakse tsitaatsõnadena ja reegli järgi hääldatakse originaalilähedaselt (loendis kursiivkirjas).

Sõnad võeti ÕS 2006-st, VL 2006-st, EKSSist ja VLi 8. trüki käsikirjast. Valik tehti sõnade hulgast, mille hääldus on eri allikates isemoodi märgitud, ei vasta selle keele hääldusele, kust sõna tuleb, või on tekitanud muid küsimusi.

Katses osales kaks eesti emakeelega katseisikute rühma. Esimesse rühma kuulus 15 kõrgharidusega isikut (v.a filoloogid) ja teise rühma 15 eesti filoloogi.

Esimese, mittefiloloogide rühma keskmine vanus oli 38 aastat. Hariduselt kuulusid sellesse rühma politoloog, bibliograaf, ajaloolased, 
sotsioloog, majandusteadlane, kehakultuurlane, bioloogid, geoloogid, ökoloogid, keemik. Neljal neist oli teadusmagistri- ja neljal doktorikraad. Ametilt olid vastajad riigikogu liige, minister, turundusspetsialist, riigiametite töötajad, Tallinna ülikooli teadurid ja professorid.

Teise, eesti filoloogide rühma keskmine vanus oli 34 aastat. Ametilt olid vastajad riigiametnik, teadusajakirja toimetajad ja peatoimetaja, eesti keele ja kirjanduse õpetaja, Tartu ülikooli magistrandid ning eesti ja üldkeeleteaduse instituudi töötajad. Neist üks oli magistri- ja üks doktorikraadiga, viis magistriõppes olevad bakalaureused.

Katsealustel paluti lugeda oma tavapärasel viisil 63 loendis olevat sõna ja öeldi, et tegemist on eestikeelsetes tekstides esinevate tsitaatsõnadega. Paluti ette kujutada situatsiooni, et loetakse kellelegi ette eestikeelset ajaleheteksti. Vastused salvestati. Katsed tehti juulist 2009 kuni märtsini 2010.

Sõnad esinesid loendis iga katseisiku jaoks eri järjekorras (et vältida järjest loetavate sõnade häälduste vastastikust mõju ja selle tõttu analüüsis vea tekkimist). Enne sõna hääldamist tuli öelda selle järjenumber ja sõna, nt esimene sõna-aadress, viiekümne viies sõna - tequila.

Keelekasutaja tegelikus spontaanses häälduses ilmnevate tendentside väljaselgitamiseks tehti analüüs. Selleks kanti salvestusest litereeritud hääldused tabelisse. Seejärel analüüsisin hääldusi, võrreldes katsealuste hääldusi omavahel ja vastava sõna hääldusega sõnastikes ning kirjeldasin huvitavamaid tendentse.

Litereerimisel tarvitati VLi 8. trükis kasutusele võetavat ${ }^{4}$ uut häälduse märkimise süsteemi ${ }^{5}$ (vt Paet 2010). Litereeriti kuulmise järgi, salvestuse kõnelainet litereerimisel ei uuritud, v.a juhul, kui oli vaja selgitada helilisust või helitust. Viimasel juhul kasutasin programmi PRAAT (Boersma, Weenink 2007).

4 Käesoleva artikli toimetamise ajaks on otsustatud siin kirjeldatud häälduse märkimise süsteemi VLi 8. trüki jaoks mõnevõrra muuta.

5 Rõhku märgitakse selles sõna rõhulise silbi esimese vokaali peal: ' (akuut) märgib II-vältelist (kerget) rõhusilpi: [a kapélla], ' (graavis) III-vältelist (rasket) silpi: [opèer]. 


\section{Analüüs ja tulemused}

Käesoleva artikli mahtu silmas pidades käsitletakse üksnes mõningaid enam huvi pakkuvaid märksõnu (katsetest põhjalikumalt vt Paet 2010).

\section{1. ad hoc (ladina)}

Selle tsitaatväljendi puhul oli eesmärk uurida vokaali pikkust, kuna ÕS ja VL märgivad seda erinevalt: ÕS 2006 ad hook, VL 2006 ad hok.

Katses selgus, et pika $o$-ga ei häälda seda tsitaatväljendit ükski katsealune. Samas ilmnes huvitav tendents: nimelt hääldas esimesest rühmast (mittefiloloogid) üheksa isikut äd hok, teisest rühmast (filoloogid) hääldas nii kolm katseisikut.

Väljend ad hoc on sageli kasutusel ka ingliskeelsetes teadustekstides ja inglispärase häälduse ülekaalu võis mõjutada see, et (esimese rühma) katsealuste hulgas oli palju teadlasi. (Vt joonis 1.)

VLi 8. trükis esitatakse hääldus kujul ad hok.

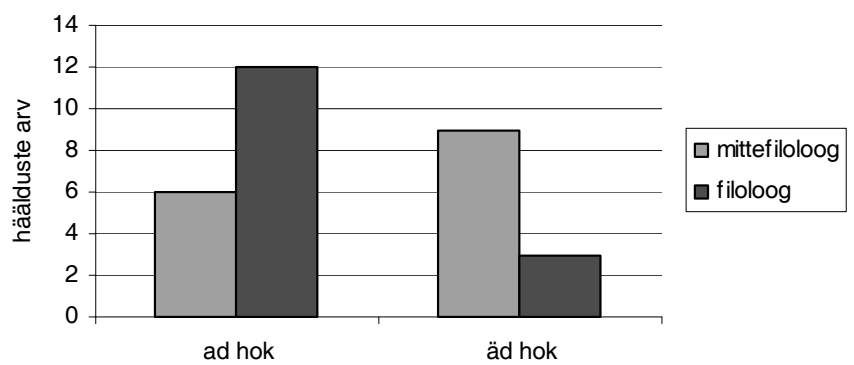

Joonis 1. Tsitaatväljendi ad hoc hääldus

2. buffet (prantsuse, VL 2006-s päritolukeel märkimata)

Eesmärk oli teada saada, kas katsealused hääldavad seda eesti- või originaalipäraselt. Sõnaraamatud esitavad häälduse järgmiselt: ÕS 2006 büfee, VL büffe', EKSS büfee.

Esimesest, mittefiloloogide rühmast hääldas originaalipäraselt büfèe üks katseisik. Hääldust bufèe oli 11 korral, üks kord hääldati bufèi, mugandhääldust búfet ja púhvet oli kumbagi ühel korral. Teisest, filoloogide rühmast hääldas kuus isikut originaalipäraselt büfèe. Ülejäänud üheksal juhul oli hääldus bufèe. (Vt joonis 2.)

Ilmselt võiks kaaluda kasutusele võtta mugand bufee, mille asemel on keelekorraldus seni üldjuhul eelistanud tsitaatkeelendit buffet või väljendit 
Rootsi laud. Võrgu-uuringud näitavad, et tegelikus kasutuses on sõna bufee üsna sage (Google). Keelenõuande andmebaasist ilmneb, et 11 küsimuse-vastuse hulgas mugandi bufee kohta on kahel korral keelenõuandja möönnud sellise mugandi võimalikkust.

VLi 8. trükk esitab häälduse büfèe.

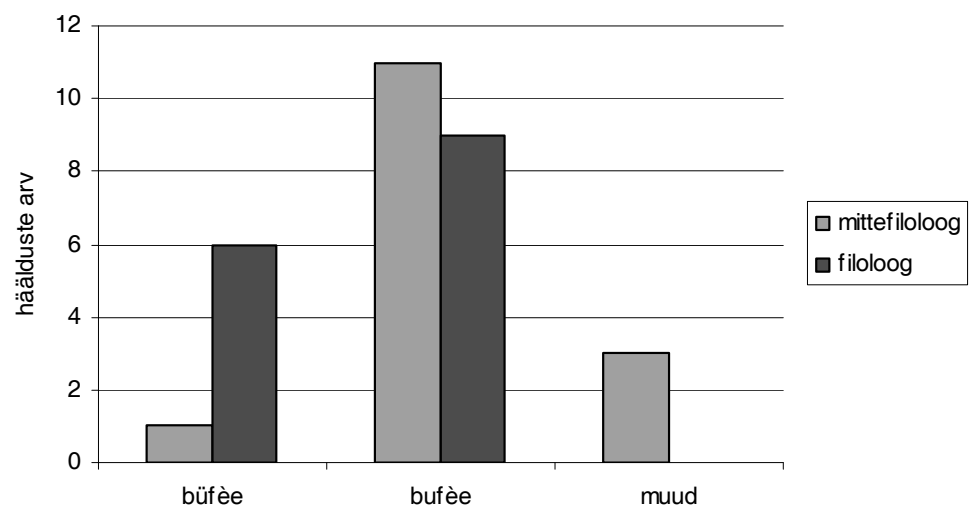

Joonis 2. Tsitaatsõna buffet hääldus

\section{3. circulus vitiosus (ladina)}

Eesmärk oli uurida, kuidas hääldatakse seda ladina päritolu tsitaatkeelendit. Sõnaraamatud esitavad häälduse järgmiselt: ÕS 2006 tsirkulus vitsioosus, VL 2006 tsi'rku- -tsiō'-, EKSS tsirku- tsioo-.

Esimese, mittefiloloogide rühma katseisikud hääldasid seitsmel korral tsírkulus vitiòosus, kahel korral sirkulus vitiòosus, kolmel korral sirkulus vitiòossus, ülejäänud hääldused olid sirkulus visòotius, kurrikúlus vitiòosus, kírkulus vitiòosus. Täiesti originaalikohaselt ei hääldanud ükski esimese rühma katsealune.

Teisest, filoloogide rühmast hääldas kaks katseisikut täiesti originaalikohaselt tsírkulus vitsiòosus, viis hääldas tsírkulus vitiòosus. Kolm isikut hääldas sirkulus vitiòosus, üks jättis hääldamata, ülejäänud hääldused olid sö́ökölös vitiòosus, tsírkulus vitòosus ja tsírkulus viitioosus, kírkulus vitiòosus. (Vt joonis 3.)

VLi 8. trükk annab häälduse kujul tsírkulus vitsiòosus. 


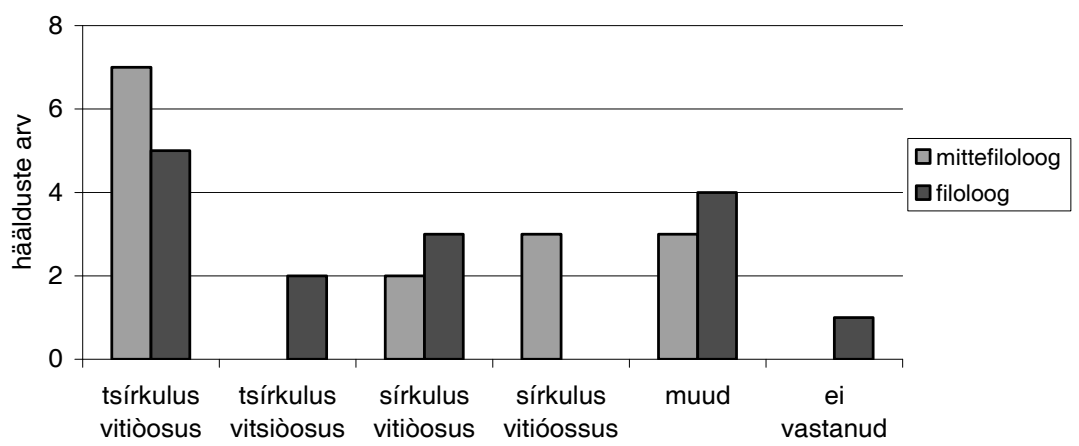

Joonis 3. Tsitaatväljendi circulus vitiosus hääldus

\section{4. gigolo (prantsuse)}

Selle sõna puhul oli eesmärk uurida, kas katsealused kasutavad originaalipärast (prantsuse keele) hääldust, mõnesse sõnastikku märgitud itaalia keele hääldust või hoopis mugandhääldust.

Sõnaraamatud esitavad häälduse järgmiselt: ÕS 2006 džigolo, VL 2006 ži ${ }^{\prime}$-, EKSS džigolo. Kõik nimetatud allikad esitavad selle märksõna tsitaatsõnana.

Põhjus, miks hääldused allikati erinevad, on päritolukeel. Nimelt märgib ÕS päritolukeeleks itaalia, EKSS päritolukeelt ei esita, kuid järelikult (häälduse põhjal otsustades) peab samuti nagu ÕS selleks itaalia keelt. VL annab päritolukeeleks prantsuse.

Prantsuse keeles hääldatakse see sõna žigolo (RC). Rõhk on prantsuse sõnades viimasel silbil.

Katsete tulemustest selgus, et valdav hääldus on gígolo. Mittefiloloogide rühmast hääldasid kõik katseisikud gígolo. Filoloogide rühmast hääldas 13 isikut gígolo ja kaks džígolo.

Seega ei hääldanud ükski 30 katsealusest seda tsitaatsõna prantsuspäraselt ja vaid kaks filoloogi pidas seda tsitaatsõnaks. Suurem osa katseisikuid pidas sõna mugandiks ega pööranud tähelepanu isegi kursiivkirjapildile. (Vt joonis 4.)

$d \check{z}$-algulist hääldust VLi 8. trükki ei lisata, sest itaalia keelde on sõna tulnud prantsuse keelest (Zingarelli 1991). Itaalia keele märkimine päritolukeeleks on olnud ekslik.

VLi 8. trükis esitatakse märksõna gigolo juures prantsuse hääldus žigolòo ning mugandhääldus gígolo. Samuti lisatakse VLi uue trüki märksõnastikku mugand gigolo püstkirjas. 


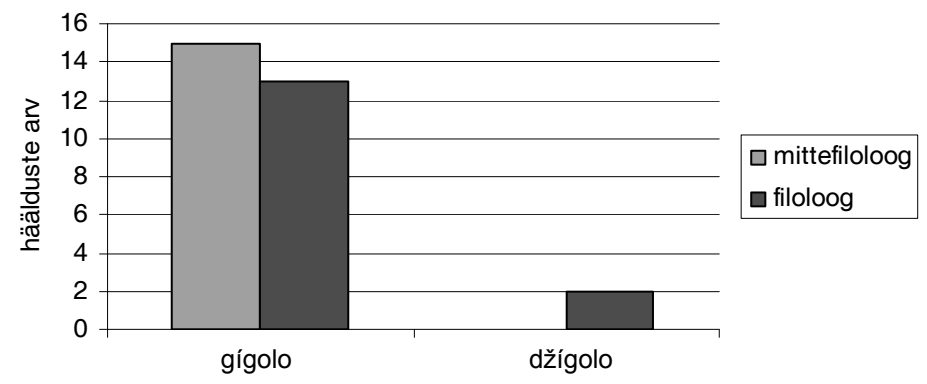

Joonis 4. Tsitaatsõna gigolo hääldus

\section{5. pizzeria (itaalia)}

Selle sõna puhul oli eesmärk uurida rõhku. Sõnaraamatud esitavad häälduse järgmiselt: ÕS 2006 pitseeria, VL 2006 -tseri'a, EKSSis märksõna puudub.

Katsed näitasid, et esimesest rühmast hääldas 14 katseisikut pitsèeria ja üks pitsería. Teisest rühmast hääldas kümme katsealust pitsèeria ja viis pitseriia.

Seega, filoloogide hulgas oli pisut rohkem neid, kes hääldas originaalipäraselt. (Vt joonis 5.) Rõhu ettepoole nihkumine on täiesti mõistetav tendents eesti keelekasutaja häälduses.

VLi 8. trükk esitab häälduse pitseríia.

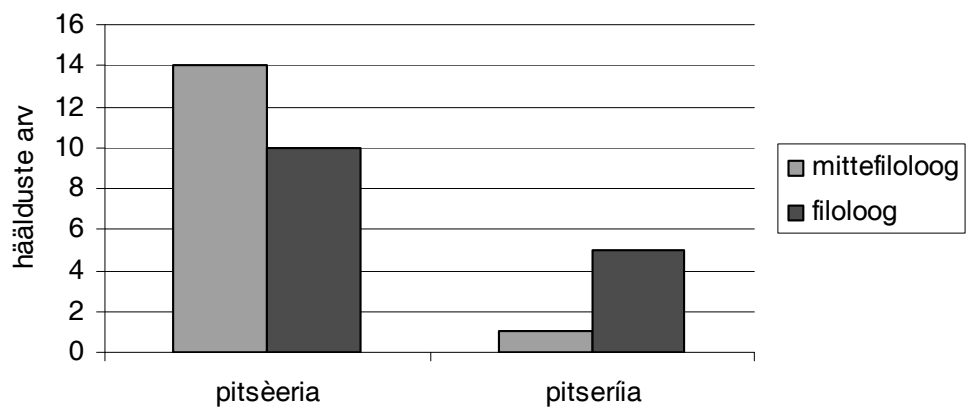

Joonis 5. Tsitaatsõna pizzeria hääldus

\section{6. premium (inglise)}

Selle sõna puhul oli eesmärk uurida, kas katseisikud hääldavad nii, nagu ÕS 2006-s märgitud, või mugandatult prèemium. ÕS 2006 esitab häälduse priimiöm, VL 2006-s ja EKSSis märksõna puudub. 
Esimese rühma katseisikuist (mittefiloloogid) hääldas 14 prèemium ja üks prìmiöm. Teisest rühmast (filoloogid) hääldasid kõik 15 mugandatult prèemium. (Vt joonis 6.) VLi 8. trükk esitab originaalhäälduse prìimiöm ja mugandhäälduse prèemium.

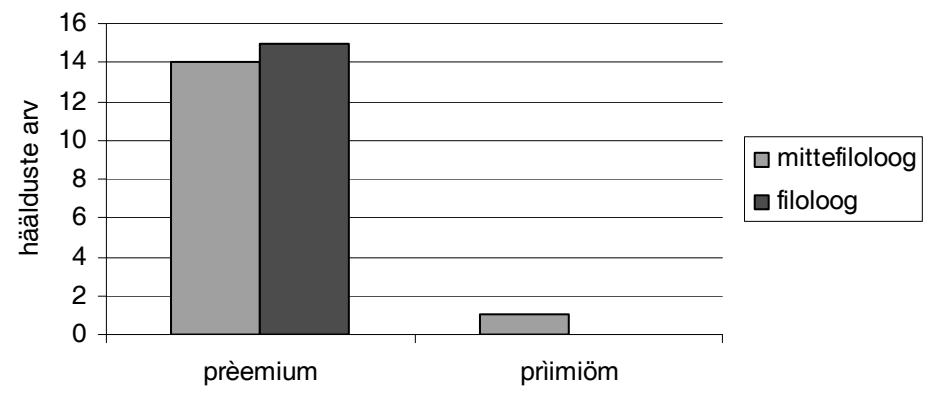

Joonis 6. Tsitaatsõna premium hääldus

\section{7. puzzle (inglise)}

Selle sõna puhul oli eesmärk välja selgitada, kas katsealused hääldavad seda originaalipäraselt pazl või mugandatult púsle.

ÕS 2006 ja VL 2006 esitavad häälduse pazl, EKSSis märksõna puudub.

Katse tulemusel selgus, et esimesest rühmast hääldas 14 isikut púsle ja üks pazl. Teine rühm hääldas kümnel korral púsle ja viiel korral pazl.

Seega kasutasid filoloogid pisut enam originaalhääldust kui mittefiloloogid, ent enamik kasutas siiski mugandhääldust. (Vt joonis 7.)

VLi 8. trükk esitab tsitaatmärksõna puzzle viitemärksõnana, juhtides sellelt mugandile pusle.

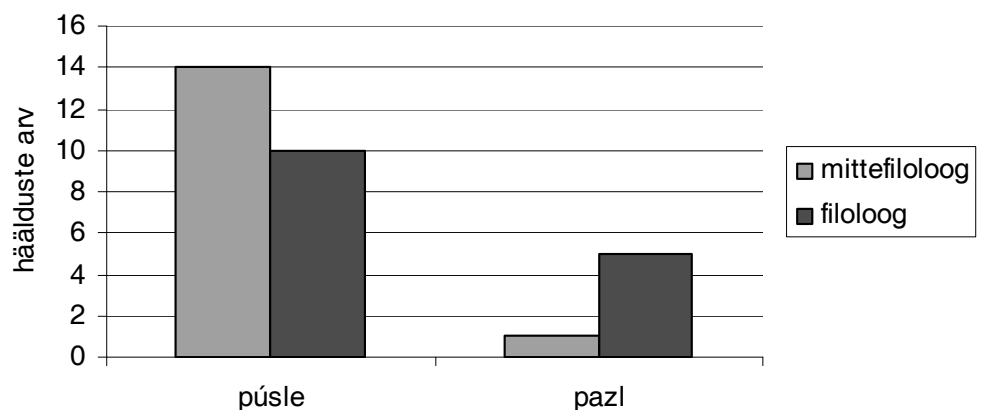

Joonis 7. Tsitaatsõna puzzle hääldus 


\section{8. thriller (inglise)}

Kuivõrd hääldus sõnaraamatuti erineb, oli selle sõna puhul eesmärk uurida, kas katsealused hääldavad originaalipäraselt või mugandatult.

Sõnaraamatud esitavad häälduse järgmiselt: ÕS 2006 triller, VL 2006 -ilö, EKSSis hääldus puudub.

Katse tulemused näitavad, et esimesest rühmast (mittefiloloogid) hääldas originaalipäraselt $\theta$ rílə(r) üks katseisik ja teisest rühmast (filoloogid) kaks. Ülejäänud hääldasid mugandatult triller.

„Thriller on jäänud tsitaatsõnaks, kuigi suulises kõnes olen kohanud seda ka kujul triller," kirjutab Tiina Leemets 2002. aastal (Leemets 2002). ÕS 2006-s on thriller antud nii tsitaatsõnana kui ka juba mugandkujul triller ning lisatud on tähendus 'põnevik' varasemale muusika valdkonna tähendusele.

Ilmselt on sõna praeguseks mugandina nii omaseks saanud, et selle esitamise korral tsitaatsõnana jäetakse kursiivkiri tähelepanuta ja hääldatakse mugandatult. (Vt joonis 8.)

VLi 8. trükk annab homonüümse märksõna tähendusega 'põnevik' ja häälduse kujul $\operatorname{\theta ril}(r)$. Märksõnalt viidatakse noolega mugandile triller. (Noolega viidatakse VLi 8. trükis ebasoovitatavalt vormilt soovitatavale.)

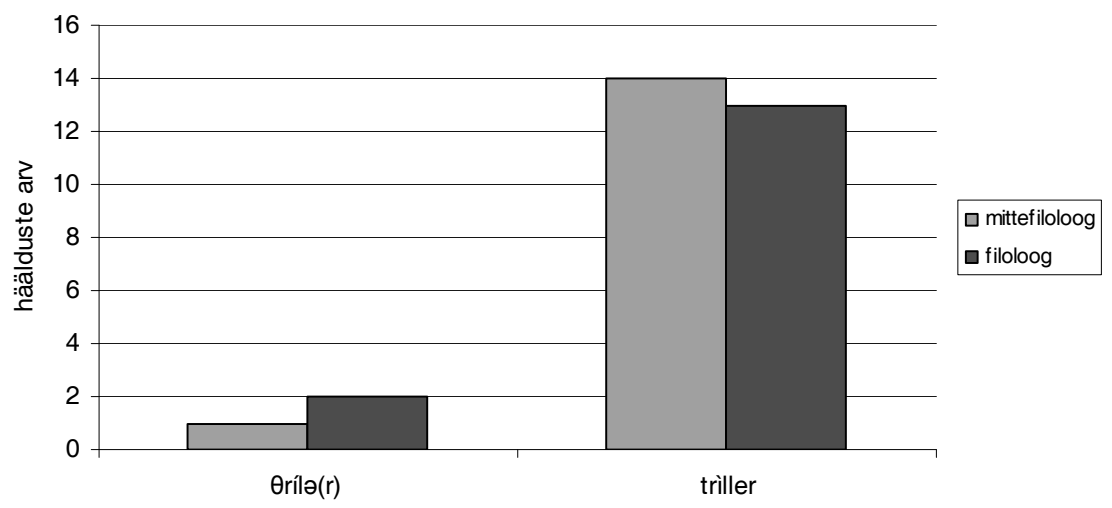

Joonis 8. Tsitaatsõna thriller hääldus 


\section{Järeldused}

Tsitaatsõnadega seonduvat kajastatakse nii eesti teaduskirjanduses, sõnaraamatute eessõnades kui ka grammatikates napilt ja peamiselt ortograafia seisukohast. Erand on 1933. aastal ilmunud Johannes Aaviku käsitlus 20 Euroopa keele hääldusest.

Eesti õigekeelsussõnaraamatud annavad üksikasjalikke koha- ja isikunimede hääldusjuhiseid keelte kaupa, samas kui isegi ei maini tsitaatsõnade häldust. Tsitaatsõnade häälduse teemat kohtab pärast Aavikut haruharva, „Eesti ortograafias” ja „Eesti keele käsiraamatus” õpetatakse, et tsitaatsõnu hääldatakse päritolukeele reeglite järgi.

Teiskeelsete sõnaraamatute eessõnades ja kasutusjuhistes pööratakse tsitaatsõnale siiski rohkem tähelepanu kui eesti sõnaraamatute sissejuhatavates osades (vt Paet 2010).

Katsete tulemustest selgus, et kõige vähem osati häldada prantsuse tsitaatsõnu ja -väljendeid, filoloogid häldasid neid oluliselt originaalilähedasemalt kui mittefiloloogid. See tulemus on ka ootuspärane, sest prantsuse keelt oldi kõige vähem õppinud ja prantsuse hääldus erineb kõige rohkem kirjapildist. Üllatavalt vähe erines ladina keelt uusladina häldusega hääldanud mittefiloloogide ja filoloogide protsent. Erinevalt muu kõrgharidusega katseisikutest olid kõik eesti filoloogid ladina keelt õppinud.

Kõige rohkem osati hääldada inglise sõnu. Neid hääldasid nii filoloogid kui ka mittefiloloogid ühteviisi originaalipäraselt (vt Paet 2010: 31). Samas kiputi inglise sõnu eestipärase mugandhääldusega hääldama.

Käesoleva uurimuse eesmärk ei olnud niivõrd püüd luua tsitaatsõnadele mugandhääldusi, lähtudes katsealuste hääldustest, kuivõrd näidata, et keeletarvitajal on tsitaatsõnade hälldusega probleeme ja et sõnaraamatute koostamisel peaks tsitaatsõnade hääldusele enam tähelepanu pöörama. Eesti sõnaraamatutes esineb tsitaatsõnade häälduste esitusel ka ebaühtlust ja vigu, mis kipuvad korduma sõnaraamatust sõnaraamatusse, sest sageli võetakse hääldusi teistest sõnaraamatutest automaatselt üle (nt sõna gigolo ekslik itaalia päritolu ja selle tõttu vale häälduse märkimine).

Alates 1990ndate algusest on valdav inglise keele tugev mõju, see kestab praeguseni ja pole täheldatav mitte üksnes sõnavaras ja semantikas, vaid ka häälduses.

Kindlasti ei saa mõistlikuks pidada selliste sõnade nagu premium või pizzeria mugandamist, sest selle järele puudub tegelik vajadus. Keele- 
korraldajad soovitavad pizzeria asemele pitsabaari, pitsarestorani ning premium'i asemele esindus-, kvaliteet-, eliit-.

Mugandada on otstarbekas sõna gigolo, VLi 8. trükk esitabki selle mugandkujul.

ÕS 2006 tsitaatsõnade häälduse esitus on mõnevõrra ebajärjekindel, taotledes kord ülimat originaalipärasust (ecstasy, premium), teine kord vastates aga rohkem kirjapildile (pizzeria, thriller, art management).

ÕS 2006 ja EKSS esitavad mitme sõna puhul sama häälduse, erinedes sellega VL 2006-st, vrd nt ad hoc, au pair, chargé d'affaires, fair play, gigolo.

Arusaadavalt ei saa siiski üksnes ja alati VLi 8. trüki häälduse esitamisel arvestada katsealuste hääldust. Näiteks hoolimata sellest, et sõna gigolo ei hääldanud ükski katsealune prantsuse hääldusega, märgitakse see VLi 8. trükis asjakohase tsitaatsõna häälduseks.

VLi 8. trükis esitatakse alati esikohal reeglikohane originaalhääldus. Kuna katsetest selgus, et enamik katsealuseid hääldab sõna gigolo mugandatult, lisatakse ka mugandhääldus. Samuti esitatakse märksõna mugandina. Mõnel juhul ei saa siiski arvestada katsealuste hääldusega, vaid tuleb teha järeldus, et asjaomase keele hääldusega on raskusi. ( $\mathrm{Nt}$ ladina tsitaatväljendi circulus vitiosus hääldusega sai hakkama vaid kaks eesti filoloogi.)

Kuna võõrsõnastiku üks ülesandeid on õpetada ka õiget hääldust, siis tuleb suhtuda mugandhäälduse esitusse siiski ettevaatlikult.

Mugandhääldust saab mõnel juhul lubada, kui see vastab eesti fonoloogilisele süsteemile. Kaks häälduskuju, millest üks on muganenum, on esitanud juba Aavik 1933. aastal (vt Paet 2010: 7).

Häälduse märkimine sõnaraamatusse võib osutuda keerukaks ja jääb paratamatult mingil määral subjektiivseks, olenedes toimetaja asjakohastest arusaamadest, võõrkeelte oskusest ja paljust muust (vrd Hartmann 2000). Reegel, mille järgi tuleb tsitaatsõnu hääldada selle keele reeglite kohaselt ja lähedaselt, kust sõna tuleb, jätab ikkagi tõlgendusvabaduse - kui lähedaselt siis ikkagi tuleb hääldada ja kui täpselt hääldust märkida? Ka ei saa asjaomase keele hääldusreegleid alati otse rakendada eesti keeles, vaid tuleb arvestada eesti keele häälduse ja grammatika võimalusi ning traditsiooni.

Sõnaraamatute koostajad ja toimetajad peaksid püüdlema selle poole, et anda hääldus, mis on võimalikult originaalilähedane, ent kasutajale 
võimalikult arusaadav. Ka peaks sõnaraamat (nii nagu ta sisaldab selgitusi muude sõnaraamatu koostamise põhimõtete ja märksõnaartikli osade kohta) sisaldama selgitusi selle kohta, mis süsteemi tsitaatsõnade ja -väljendite häälduse märkimiseks kasutatakse.

Eri keeltest pärinevate võõrapärase hääldusega sõnade järjest ja ilma kontekstita lugemine ning hääldamine ei ole kindlasti autentne situatsioon. Kui inimene on häälestunud ühele keelele, siis on tal arvatavasti raske seejärel kohe öelda teisest keelest pärit sõna või lauset.

Ometi annab selline eri keeltest pärinevate sõnade järjest ja ilma kontekstita hääldamine siiski ülevaate mõnesugustest tendentsidest kõrgharitud, eesti emakeelega keelekasutaja tsitaatsõnahäälduses.

\section{Kokkuvõte}

Tsitaatsõnade häälduse kohta keelte kaupa võib öelda järgmist.

Ladina päritolu tsitaatsõnu ja -väljendeid oli häälduskatsete sõnaloendis 12. Nende häälduses oli vaatluse all rõhk, vokaali pikkus ning tähtede ja täheühendite $c, t i, a e, q$ hääldus. Käesolevas analüüsis loetakse originaalhäälduseks uusladina, mitte klassikalise ladina keele hääldust.

Eriti keeruliseks osutus katsealustele traditsioonilise ladina vokaalipikkusega hääldamine: opus citatum, persona non grata ja sic! ei hääldanud nn traditsioonilise uusladina hääldusega ükski katseisik kummastki rühmast (opus hääldati pika $o$-ga, non lühikese $o$-ga ja sic lühikese $i$-ga) (vt Paet 2010: 92).

Nagu nt prantsuse sõnu, nii hääldati ka ladina sõnu (nt ad hoc, circulus vitiosus) kohati inglispäraselt.

Mittefiloloogid hääldasid keskmiselt 32\% ladina tsitaatsõnadest ja -väljenditest nn traditsioonilise uusladina hääldusega. Filoloogid hääldasid 39\% ladina tsitaatsõnadest ja -väljenditest nn traditsioonilise uusladina hääldusega. Tuleb märkida, et kõik filoloogid olid õppinud ladina keelt, enamik mittefilolooge ei olnud.

Inglise päritolu tsitaatsõnu ja -väljendeid oli häälduskatsete sõnaloendis 18 .

Mõlemad rühmad hääldasid keskmiselt $64 \%$ inglise sõnadest originaalipäraselt.

Märkimisväärne on tendents, et ehkki suur hulk katseisikuid hääldas mitteinglise sõnu inglispäraselt, hääldas enamik katseisikuid seevastu 
inglise tsitaatsõnu hoopis eestipäraselt, nt premium (1. rühm u 93\%, 2. rühm $86 \%$ ), puzzle (1. rühm $93 \%$, 2. rühm $67 \%$ ), thriller (1. rühm $93 \%$, 2. rühm $86 \%$ ).

Võib üsna kindlalt väita, et kui tsitaatsõnaga paralleelselt on käibel mugand, siis hääldatakse ka tsitaatsõna mugandatult (nt thriller, puzzle).

Prantsuse sõnu oli häälduskatsete sõnaloendis 13 .

Mittefiloloogide rühm hääldas prantsuse sõnadest $21 \%$ originaalipäraselt, filoloogide rühm hääldas neist $43 \%$ originaalipäraselt.

Prantsuse sõnadest hääldati sõnu au pair, buffet, chargé d'affaires, enfant terrible, grand prix kohati inglise hääldusega.

Peale ladina ja prantsuse päritolu sõnade hälldati mugandatult või inglispäraselt ka itaalia sõnu, nt pizzeria, lamentabile.

Kui ladina ja prantsuse päritolu keelendite puhul oli sõnaraamatule vastavat hääldust suhteliselt vähe peamiselt seepärast, et ei osatud hääldada, siis inglise keelendite puhul peamiselt seepärast, et domineeris eestipärane mugandhääldus.

VLi 8. trükis antakse mugandhääldus seitsmel häälduskatsetes uuritud sõnal ja sõnaühendil. Need on catering, fair play, gigolo, incognito, mezzo piano, performance, premium.

Mõnel märksõnal (casting, crêperie, ecstasy, musical, performance, slogan) korrigeeritakse originaalhäälduse esitust (vt Paet 2010).

Mugandina otsustati VLi 8. trükki lisada sõna gigolo. Tsitaatsõnad puzzle ja thriller otsustati jätta üksnes viitemärksõnadeks, millelt juhatatakse noolega mugandkuju juurde.

\section{Kirjandus}

Aavik, Johannes 1936. Eesti õigekeelsuse õpik ja grammatika. Noor-Eesti Kirjastus Tartus.

Aavik, Johannes 1933 = Johannes Aavik 2005. 20 Euroopa keelt. Toim. Helgi Vihma. Tallinn: Johannes Aaviku Selts.

EKG I-II = Mati Erelt, Reet Kasik, Helle Metslang, Henno Rajandi, Kristiina Ross, Henn Saari, Kaja Tael, Silvi Vare 1995, 1993. Eesti keele grammatika. I. Morfoloogia. Sõnamoodustus. II. Süntaks. Lisa: kiri. Trükki toimetanud Mati Erelt peatoimetajana, Tiiu Erelt, Henn Saari ja Ülle Viks.Tallinn: Eesti Teaduste Akadeemia Eesti Keele Instituut (Keele ja Kirjanduse Instituut). 
EKK = Mati Erelt, Tiiu Erelt, Kristiina Ross 2007. Eesti keele käsiraamat. Kolmas, täiendatud trükk. Tallinn: Eesti Keele Sihtasutus.

EKKSS I,1 = Eesti kirjakeele seletussõnaraamat. I köide (A-J), 1. vihik (A-bakhantlik), 1988. Erich Raiet (peatoim.), Rudolf Karelson (toim.), Leena Kiivit, Ilse Kont (toim.), Helga Laanpere, Tiina Lias, Arnold Pikamäe (toim.), Valve Põlma (toim.) ja Feliks Vakk. Eesti NSV Teaduste Akadeemia Keele ja Kirjanduse Instituut. Tallinn: Valgus.

EKKSS VI,2 = Eesti kirjakeele seletussõnaraamat. VI köide (T-V), 2. vihik (tinakatk-tundlus), 2002. Peatoim. Rudolf Karelson, Leidi Veskis ja Mai Tiits. Eesti Keele Instituut. Tallinn: Eesti Keele Sihtasutus.

EKSS $=$ Eesti keele seletav sõnaraamat. 1-6, 2009. „Eesti kirjakeele seletussõnaraamatu" 2., täiendatud ja parandatud trükk. Toim. Margit Langemets, Mai Tiits, Tiia Valdre, Leidi Veskis, Ülle Viks, Piret Voll. Eesti Keele Instituut. Tallinn: Eesti Keele Sihtasustus.

EKÕS = Eesti keele õigekirjutuse-sõnaraamat. 1918. Eesti Kirjanduse Seltsi väljaanne. Tallinn: K.-Ü. „Rahvaülikooli” kirjastus.

Erelt, Tiiu 1995. Eesti ortograafia. [Tallinn: Eesti Keele Sihtasutus].

EÕS = Eesti õigekeelsuse-sõnaraamat. I-III, 1925-1937. „Eesti keele õigekirjutuse-sõnaraamatu" II täiendatud ja parandatud trükk. Tartu: Eesti Kirjanduse Seltsi kirjastus.

Hartman, James 2000. Dictionary pronunciations: mine or their or yours? American Speech 75/3, 250-252.

Kõrv, August Voldemar 1935. Õpilase võõrsõnastik. Tallinn: Ilo.

Leemets, Tiina 2002. Inglise laenud ja mõjutused 20. sajandi lõpu eesti keele sõnavaras. Magistritöö. Käsikiri Tartu Ülikooli eesti ja üldkeeleteaduse instituudis.

Leemets, Tiina 2003. Inglise laenud sajandivahetuse eesti keeles. - Keel ja Kirjandus 8, 571-584.

LES $=$ Ladina-eesti sõnaraamat. Glossarium Latino-Estonicum. 1986. Koost. Richard Kleis, Ülo Torpats, Lalla Gross, Heinrich Freymann. Tallinn: Valgus.

MKN = Peeter Päll 1999. Maailma kohanimed. Tallinn: Eesti Keele Sihtasutus.

Nurm, Ernst 1935. Ortofoonilisi küsimusi. - Eesti Keel, 185-190.

Paet, Tiina 2010. Tsitaatsõna häälduse esitus „Võõrsõnade leksikonis”. Magistritöö. Käsikiri Tartu Ülikooli eesti ja üldkeeleteaduse instituudis; http:// dspace.utlib.ee/dspace/bitstream/10062/15079/1/paet_tiina.pdf.

Raiet, Erich 1966. Võõrsõnade kuju sõltuvus lähte- ja vahendajakeeltest tänapäeva eesti kirjakeeles. Väitekiri filoloogiateaduste kandidaadi kraadi taotlemiseks. Tallinn: Eesti NSV Teaduste Akadeemia Keele ja Kirjanduse Instituut. 
RC $=$ Le Grand Robert \& Collins électronique (PC/Mac). 2004. Dictionnaires Le Robert / Sejer.

SVL = Suur võõrsõnade leksikon. 1937. Koost. H. Haljaspõld. Teine, täiendatud trükk. Tallinn: Kirjastus Raamat.

SÕS = Suur õigekeelsus-sõnaraamat. Eesti NSV Teaduste Akadeemia Keeleja Kirjandusinstituut. 1. vihik, 1948. Tartu: RK Teaduslik Kirjandus; 2. vihik, 1951. Tallinn: Eesti Riiklik Kirjastus.

Zingarelli 1991 = Il Nuovo Zingarelli minore. Vocabolario della lingua italiana di Nicola Zingarelli. Undicesima edizione minore. Bologna: Zanichelli.

Tauli, Valter 1968. Keelekorralduse alused. Stockholm: Eesti Raamat.

Tauli, Valter 1972. Eesti grammatika I. Hääliku-, vormi- ja sõnaõpetus. Institutionen för finsk-ugriska språk. Soome-Ugri Keelte Instituut. Upsala.

Valgma, Johannes, Nikolai Remmel 1968. Eesti keele grammatika. Käsiraamat. Tallinn: Valgus.

VL 1930-1931 = Võõrsõnade leksikon. I-VIII. Koost. Herbert Haljaspõld. Tallinn: Kirjastus Elu.

VL 1961 = Võõrsõnade leksikon. Koost. Richard Kleis, Johannes Silvet, Eduard Vääri. Tallinn: Eesti Riiklik Kirjastus.

VL 1983 = Richard Kleis, Johannes Silvet, Eduard Vääri. Võõrsõnade leksikon. Viies trükk. Tallinn: Valgus, 1983.

VL 2000 = Eduard Vääri, Richard Kleis, Johannes Silvet. Võõrsõnade leksikon.

Kuues, uuendatud trükk. Parandanud ja täiendanud Eduard Vääri. Tallinn: Valgus.

VL 2006 = Eduard Vääri, Richard Kleis, Johannes Silvet. Võõrsõnade leksikon.

Seitsmes, parandatud ja täiendatud trükk. [Tallinn:] Valgus.

VS 1999 = Võõrsõnastik. Tallinn: Tea.

VVS = Väike võõrsõnastik. 1933. Koost. Herbert Haljaspõld. Tartu: Noor-Eesti Kirjastus.

VÕS 1946 = Väike õigekeelsus-sõnaraamat. Koost. Elmar Muuk. Tartu: RK Teaduslik Kirjandus.

ÕS $1960=$ Õigekeelsuse sõnaraamat. ENSV Teaduste Akadeemia Keele ja Kirjanduse Instituut. Toim. Ernst Nurm, Erich Raiet, Magnus Kindlam. Tallinn: Eesti Riiklik Kirjastus.

ÕS 1976 = Õigekeelsussõnaraamat. ENSV Teaduste Akadeemia Keele ja Kirjanduse Instituut. Toim. Rein Kull, Erich Raiet. Tallinn: Valgus.

ÕS 1999 = Eesti keele sõnaraamat ÕS 1999. Toim. Tiiu Erelt. Koost. Tiina Leemets, Sirje Mäearu, Maire Raadik ja Tiiu Erelt. Eesti Keele Instituut. Tallinn: Eesti Keele Sihtasutus.

ÕS 2006 = Õigekeelsussõnaraamat ÕS 2006. Toim. Tiiu Erelt. Koost. Tiiu Erelt, Tiina Leemets, Sirje Mäearu, Maire Raadik. Eesti Keele Instituut. Tallinn: Eesti Keele Sihtasutus. 


\section{Interneti-allikad}

Boersma, Paul, David Weenink 2007. Praat: doing phonetics by computer (Version 4.6.31). http://www.praat.org/ (08.10.2007).

Google $=$ www.google.com

http://www.eki.ee/dict/qs2006/index

http://www.eki.ee/dict/ekss/index 


\title{
Estonian pronunciation of unadapted foreign words and expressions (linguistic foreignisms) and its presentation in dictionaries
}

\author{
Tiina Paet
}

The aim of the present paper is to develop an insight into how unadapted foreign words are pronounced in Estonian.

The study was motivated by some problems encountered in the process of editing the $8^{\text {th }}$ edition of the Estonian dictionary of foreign words (Võorrsonnade leksikon). Formerly, both this dictionary and various monolingual Estonian dictionaries presented their pronunciation inconsistently.

The present study aims to find out whether and to what extent the users follow the pronunciation presented in dictionaries, in particular, how close is the pronunciation of university-educated native speakers of Estonian to the original pronunciation of the foreignism in the source language?

The analytical part is based on 63 entries (52 of which are unadapted foreign words and expressions) drawn from the $7^{\text {th }}$ edition of the Estonian dictionary of foreign words (VL 2006), the explanatory dictionary of standard Estonian (EKSS), the dictionary of standard Estonian ÕS 2006 (ÕS 2006), and the manuscript of the $8^{\text {th }}$ edition of the Estonian dictionary of foreign words (VL).

The pronunciation test contained 12 foreignisms of Latin, 18 of English, and 13 of French origin.

Keywords: lexicography, lexicology, adapted pronunciation, foreign word, lexicon of foreign words

Tiina Paet

keelekorraldusosakond

Eesti Keele Instituut

Roosikrantsi 6

10119 Tallinn

Tiina.Paet@eki.ee 